\title{
HUBUNGAN KEPEMIMPINAN KEPALA SEKOLAH TERHADAP MANAJEMEN BERBASIS SEKOLAH
}

\author{
Sogi Hermanto \\ Prodi Manajemen Pendidikan FKIP Universitas Parahyangan \\ Jalan Ciumbuleuit No.94, Bandung \\ e-mail:1953sogi12@gmail.com
}

\begin{abstract}
Abstrak: Tujuan penelitian ini untuk mengetahui: (1) deskripsi Kepemimpinan Kepala Sekolah Menengah Pertama (SMP) Negeri, (2) deskripsi Manajemen Berbasis Sekolah (MBS), dan (3) hubungan yang signifikan antara Kepemimpinan Kepala Sekolah dan Manajemen Berbasis Sekolah (MBS). Metode penelitian mengunakan motode kuatitatif dengan jenis penelitian koresional. Hasil penelitian menunjukkan bahwa: (1) Kepemimpinan Kepala Sekolah Menengah Pertama (SMP) Negeri Se Kecamatan Pahandut di Kota Palangka Raya, menunjukan bahwa kategori "Amat Baik" sebanyak 20,90\%, nilai kategori "Baik" sebanyak 25,00\%, nilai kategori "Cukup" sebanyak 47,73\%, dan nilai kategori "Kurang" sebanyak 6,37\%. (2) Manajemen Berbasis Sekolah (MBS) di Sekolah Menengah Pertama (SMP) Negeri Se Kecamatan Pahandut Kota Palangka Raya, menunjukan bahwa kategori "Amat Baik" sebanyak 9,09\%, nilai kategori "Baik" sebanyak 31,82\%, nilai kategori "Cukup" sebanyak 50\%, dan nilai kategori "Kurang" sebanyak 9,09\%. dan (3) ada hubungan yang signifikan antara Kepemimpinan Kepala Sekolah terhadap Manajemen Berbasis Sekolah (MBS) di Sekolah Menengah Pertama (SMP) Negeri SeKecamatan Pahandut Kota Palangka Raya.
\end{abstract}

Kata Kunci: Kepemimpinan kepala sekolah, manajemen berbasis sekolah

Abtract: The purpose of this study to determine: (1) a description of Public Junior High School Principal Leadership, (2) a description of School Based Management (SBM), and (3) a significant relationship between Leadership Principals and School Based Management (SBM). The research method uses quantitative method, corelational research. The results showed that: (1) Principal Leadership of Public Junior High School within Pahandut District city of Palangkaraya, shows that the category of "Very Good" as much as $20.90 \%$, the value of the "Good" category as much as $25.00 \%$, the value of category "Enough" as much as $47.73 \%$, and the value of the category "Less" as much as 6.37\%. (2) School Based Management (SBM) at Public Junior High School within Pahandut District city of Palangkaraya, shows that the "Very Good" category as much as $9.09 \%$, the value of the "Good" category as much as $31.82 \%$, the value of "Enough" category as much as $50 \%$, and the value of the "Less" category of as much as $9.09 \%$. and (3) there is a significant relationship between thePrincipal Leadership and the School Based Management (SBM) at Public Junior High School within Pahandut District city of Palangkaraya.

Keyword: School principal leadership, school based management

Pendidikan Nasional bertujuan mencerdaskan bangsa dan mengembangkan masyarakat Indonesia seutuhnya, Yaitu manusia yang beriman kepada Tuhan Yang Maha Esa dan berbudi luhur, memiliki kepribadian yang mantap dan mandiri, memiliki keterampilan dan pengetahuan, kesehatan jasmani dan rohani, serta rasa tanggung jawab kemasyarakatan dan kebangsaan. Hal itu sesuai Undang-Undang RI Nomor 20 Tahun 2003 tentang Sistim Pendidikan Nasional Bab I pasal (1) disebutkan bahwa: "pendidikan dapat diartikan sebagai usaha sadar terencana untuk mewujudkan suasana belajar dan proses pembelajaran agar peserta didik secara aktif mengembangkan potensi dirinya untuk memiliki kekuatan spiritual keagamaan, 
pengendalaian diri, kepribadian, kecerdasan, akhlak mulia, serta keterampilan diperlukan dirinya, masyarakat, bangsa dan negara".

Upaya mencerdasakan kehidupan bangsa menjadi tanggung jawab pendidikan, terutama dalam mempersiapkan peserta didik menjadi subjek yang bertakwa kepada Tuhan Yang Maha Esa, berakhlak mulia, tangguh, kreatif, mandiri, demokratis, dan profesional pada bidangnya masing-masing. Menyadari hal tersebut. pemerintah telah melakukan penyempurnaan sistem pendidikan. Upaya tersebut antara lain dikeluarkan UU Nomor 22 dan 25 Tahun 1999 tentang Otonomi Daerah, serta dikuti oleh penyempurnaan UU Sistem Pendidikan Nasional, yang secara langsung berpengaruh terhadap perencanaan, pelaksanaan, dan evaluasi pendidikan. Jika sebelumnya manajemen pendidikan merupakan wewnang pusat dengan paradigma top-down atau sentralistik, maka dengan berlakunya undangundang tersebut kewenangan bergeser pada pemerintah daerah kota dan kabupaten dengan paradigma buttom-up atau desentralistik, dalam wujud pemberdayaan sekolah, yang meyakini bahwa untuk meningkatkan kualitas pendidikan sedapat mungkin keputusan seharusnya dibuat oleh mereka yang berada di garis depan, yang bertanggung jawab terhadap pelaksanaan kebijakan, dan terkena akibatnya secara langsung, yakni guru dan kepala sekolah.

Dari uraian tersebut menyebabkan ketertarikan untuk merngkaji: "Hubungan Kepemimpinan Kepala Sekolah terhadap Manajemen Berbasis Sekolah di SMP Negeri se Kecamatan Pahandut Palangka Raya." Latar (setting) penelitian bertempat di 4 Sekolah Menengah Pertama (SMP) Negeri Kecamatan Pahandut Kota Palangka Raya.

Tujuan penelitian adalah untuk mengetahui: (1) deskripsi Kepemimpinan Kepala Sekolah Menengah Pertama (SMP) Negeri Se Kecamatan Pahandut di Kota Palangka Raya, (2) deskripsi Manajemen Berbasis Sekolah (MBS) di Sekolah Menengah Pertama (SMP) Negeri Se Kecamatan Pahandut Kota Palangka Raya, dan (3) ada hubungan yang signifikan antara Kepemimpinan Kepala Sekolah terhadap Manajemen Berbasis Sekolah (MBS) di Sekolah Menengah Pertama (SMP) Negeri Se Kecamatan Pahandut Kota Palangka Raya.

\section{METODE}

Rancangan penelitian ini menggunakan pendekatan kuantitatif, pendekatan kuantitatif merupakan gejala-gejala hasil pengamatan yang berwujud data diukur dan diwujudkan dalam bentuk angka dan dianalisa dengan teknik statistik. Sedang ditinjau dari pola atau sifat penelitian termasuk jenis penelitian korelasional, karena peneliti berusaha menelaah hubungan antara satu variabel dengan variabel lainnya. Menurut Sumadi Suryabrata, (1993:26) menyatakan bahwa: "Tujuan penelitian korelasional adalah untuk mendeteksi sejauh mana variasi-variasi pada satu atau lebih faktor lain berdasarkan koefisien korelasi".

Dalam penelitian ini variabel yang diteliti terdiri dari dua variabel yaitu variabel bebas Kepemimpinan Kepala Sekolah (X), dan Manajemen Berbasis Sekolah (Y).

Hubungan antar variabel tersebut dapat digambarkan sebagai berikut:

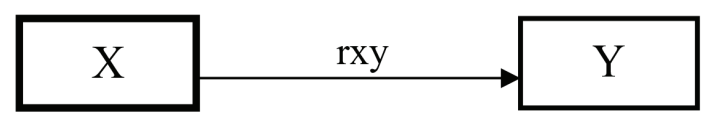

Keterangan:

$\mathrm{X}=$ Kepemimpinan Kepala Sekolah

$\mathrm{Y}=$ Manajemen Berbasis Sekolah (MBS)

$r=\quad$ Korelasi atau hubungan

Gambar 1 Hubungan Kepemimpinan Kepala Sekolah dengan MBS

Berdasarkan anak panah pada Gambar 1 menunjukkan bahwa tinggi rendahnya Kepemimpinan Kepala Sekolah (X) memengaruhi tingkat keberhasilan pelaksanaan Manajemen Berbasis Sekolah (Y). Berdasarkan sifat jenis penelitian korelasional, yang berusaha mengkaji kuatnya hubungan antar variabel penelitian. Ini seperti dinyatakan Moore (1983) bahwa tingkat hubungan antar dua variabel diukur melalui koefisien korelasi.

Sumber data diperoleh dari guru-guru di Sekolah Menengah Pertama (SMP) Negeri se Kecamatan Pahandut di Kota Palangka Raya dan ditetapkan sebagai populasi dalam penelitian ini yaitu sebanyak 178 orang guru. Sampel ditarik $25 \%$ dari keseluruhan jumlah populasi, sehingga sampel diperoleh sebanyak 44 orang guru. 
Teknik pengumpulan data diambil dengan menggunakan angket tertutup, observasi, dokumentasi. Validitas angket dilihat dari validitas isi (content validity). Sedangkan reliabilitas dihitung setelah angket diujicobakan dengan menggunakan rumus Alpa. Angket diujicobakan kepada guru di Sekolah Menengah Pertama (SMP) Negeri se Kecamatan Pahandut di Kota Palangka Raya yang tidak dikenakan sebagai sampel penelitian. Angket disusun dengan model skala likert. Untuk angket Kemimpinan Kepala Sekolah berjumlah 20 butir pertanyaan, masingmasing butir pertanyaan memiliki kriteria 4 alternatif jawaban, dan angket manajemen berbasis sekolah (MBS) sebanyak 12 butir pertanyaan, masing-masing butir pertanyaan memiliki kriteria 4 alternatif jawaban.

Teknik analisis data dengan menggunakan teknik analisis deskriptif kuantitatif yang digambarkan dalam bentuk distribusi frekuensi terhadap kategori-kategori skala penilaian yang telah ditentukan, dan uji hipotesis menggunakan rumus product moment dari Pearson. Dari hasil analisis tersebut kemudian dideskripsikan untuk mengambil kesimpulan tentang masing-masing indikator berdasarkan kriteriannya.

\section{HASIL}

Angket Kepemimpinan Kepala Sekolah berjumlah 20 butir pertanyaan, masing-masing butir pertanyaan memiliki kriteria 4 alternatif jawaban yang disebarkan terhadap 44 orang guru dengan target nilai paling tinggi 80 dan paling rendah 20. Berdasarkan hasil data yang terkumpul diketahui bahwa nilai tertinggi yang diperoleh dari responden adalah 80 dan nilai terendah adalah 41 .

Berdasarkan tabulasi di atas dapat diketahui bahwa Deskripsi Kepemimpinan Kepala Sekolah di Sekolah Menengah Pertama (SMP) Negeri se Kecamatan Pahandut Kota Palangka Raya menunjukan temuan bahwa kategori "Amat Baik" sebanyak 20,90\% (9 orang guru dengan skor antara 71 - 80, nilai kategori "Baik" sebanyak $25,00 \%$ (11 orang guru) dengan skor antara 61 70, nilai kategori "Cukup" sebanyak 47,73\% (21 orang guru) dengan skor antara $51-60$, dan nilai kategori "Kurang" sebanyak 6,37\% (orang guru) dengan skor antara 41- 50.

Angket Manajemen berbasis sekolah sebanyak 12 butir pertanyaan, masing-masing butir pertanyaan memiliki kriteria 4 alternatif jawaban yang disebarkan terhadap 44 orang guru dengan target nilai paling tinggi 48 dan paling rendah 12. Berdasarkan hasil data yang terkumpul diketahui bahwa nilai tertinggi yang diperoleh dari responden adalah 48 dan nilai terendah adalah 31

Berdasarkan tabulasi di atas dapat diketahui bahwa Deskripsi Manajemen Berbasis Sekolah di Sekolah Menengah Pertama (SMP) Negeri se Kecamatan Pahandut Kota Palangka Raya menunjukan temuan bahwa kategori "Amat Baik" sebanyak 9,09\% (4 orang guru) dengan

Tabel 1 Distribusi data Kepemimpinan Kepala Sekolah (X)

\begin{tabular}{lcccr}
\hline \multicolumn{1}{c}{ No } & Interval & Kategori (k) & Frekuensi (f) & \% \\
\hline 1 & $71-80$ & Amat Baik & 9 & 20,90 \\
2 & $61-70$ & Baik & 11 & 25,00 \\
3 & $51-60$ & Cukup & 21 & 47,73 \\
4 & $41-50$ & Kurang & 3 & 6,37 \\
Jumlah & & & 44 & $100 \%$ \\
\hline
\end{tabular}

Tabel 2 Distribusi data Manajemen Berbasis Sekolah (Y)

\begin{tabular}{|c|c|c|c|c|}
\hline No & Interval & Kategori (k) & Frekuensi (f) & $\%$ \\
\hline 1 & $44-48$ & Amat Baik & 4 & 9,09 \\
\hline 2 & $39-43$ & Baik & 14 & 31,82 \\
\hline 3 & $34-38$ & Cukup & 22 & 50,00 \\
\hline 4 & $29-33$ & Kurang & 4 & 9,09 \\
\hline \multicolumn{3}{|c|}{ Jumlah } & 44 & $100 \%$ \\
\hline
\end{tabular}


skor antara 44-48, nilai kategori "Baik" sebanyak $31,82 \%$ (14 orang guru) dengan skor antara 3943, nilai kategori "Cukup" sebanyak 50\% (22 orang guru) dengan skor antara 34-38, dan nilai kategori "Kurang" sebanyak 9,09\% (4 orang guru) dengan skor antara 29-33.

Hipotesis dalam penelitian ini diuji dengan menggunakan rumus product moment dari Pearson untuk melihat hubungan antara variabel Kepemimpinan Kepala Sekolah (X) dengan variabel Manajemen Berbasis Sekolah (Y). Hasil uji hipotesis disajikan sebagai berikut: Hubungan Kepemimpinan Kepala Sekolah terhadap Manajemen Berbasis Sekolah di Sekolah Menengah Pertama (SMP) Negeri se Kecamatan Pahandut Kota Palangka Raya.

Ha : "Ada hubungan yang signifikan antara Kepemimpinan Kepala Sekolah terhadap Manajemen Berbasis Sekolah di Sekolah Menengah Pertama (SMP) Negeri se Kecamatan Pahandut Kota Palangka Raya".

Ho : "Tidak ada hubungan yang signifikan antara Kepemimpinan Kepala Sekolah terhadap Manajemen Berbasis Sekolah di Sekolah Menengah Pertama (SMP) Negeri se Kecamatan Pahandut Kota Palangka Raya".

Berdasarkan perhitungan menggunakan statistik mengenai Hubungan Kepemimpinan Kepala Sekolah terhadap Manajemen Berbasis Sekolah di Sekolah Menengah Pertama (SMP) Negeri se Kecamatan Pahandut Kota Palangka Raya, diperoleh rxy hitung $=0,999$. Dengan rxy hitung 0,999 adalah lebih besar dari $\mathrm{r}$ tabel $=0,304$ pada taraf signifikan $5 \%$ dan taraf signifikan $1 \%=0,393$, maka Ha diterima, dan Ho ditolak. Berarti ada hubungan positif yang signifikan antara Kepemimpinan Kepala Sekolah terhadap Manajemen Berbasis Sekolah di Sekolah Menengah Pertama (SMP) Negeri se Kecamatan Pahandut Kota Palangka Raya.

\section{PEMBAHASAN}

Pembahasan penelitian ini difokuskan pada pembahasan pada hasil pengujian hipotesis dari hubungan Kepemimpinan Kepala Sekolah terhadap Manajemen Berbasis Sekolah di Sekolah Menengah Pertama (SMP) Negeri se Kecamatan Pahandut Kota Palangka Raya. Hasil penelitian menunjukkan bahwa ada hubungan yang positif antara Kepemimpinan Kepala Sekolah terhadap Manajemen Berbasis Sekolah di Sekolah Menengah Pertama (SMP) Negeri se Kecamatan Pahandut Kota Palangka Raya. Dengan demikian bahwa dalam penelitian ini Kepemimpinan Kepala Sekolah dapat mempengaruhi Manajemen Berbasis Sekolah di Sekolah Menengah Pertama (SMP) Negeri se Kecamatan Pahandut Kota Palangka Raya.

Pola hubungan yang terdapat antara variabel bebas $(\mathrm{x})$ dan variabel terikat (y) dapat digambarkan sebagai berikut.

Hubungan antara variabel bebas $\mathrm{x}$ dan variabel terikat y

\begin{tabular}{|c|c|c|}
\hline $\begin{array}{c}\text { Kepemimpinan Kepala } \\
\text { Sekolah } \\
(\mathrm{X})\end{array}$ & \multicolumn{1}{c}{$r x y=0,999$}
\end{tabular}$\stackrel{\begin{array}{c}\text { Manajemen Berbasis Sekolah } \\
\text { (Y) }\end{array}}{\longrightarrow}$

Dari hasil perhitungan ternyata angka hubungan (korelasi) antara variabel $\mathrm{X}$ dan variabel $Y$ tidak bertanda negatif, berarti diantara kedua variabel tersebut terdapat hubungan positif (korelasi berjalan searah). Dengan demikian memperhatikan besarnya rxy $=0,999$ yang besarnya berkisar antara 0,90 - 1,00 (Anas Sudijono, 2000:180), berarti korelasi antara variabel $\mathrm{X}$ dan variabel $\mathrm{Y}$ itu termasuk korelasi positif yang sangat kuat / sangat tinggi.

Dalam Undang-undang RI Nomor 20 Tahun 2003 tentang Sistem Pendidikan Nasional Bab XI pasal 39 ayat (1) dan ayat (2) di sebutkan: "tenaga kependidikan bertugas melaksanakan administrasi, pengelolaan, pengembangan, pengawasan dan pelayanan teknis untuk menunjang pendidikan pada satuan pendidikan".

Paradigma bottom-up atau disentralistik kini disebut dengan Manajemen Berbasis Sekolah (MBS) atau School Based Management (SBM). Program MBS merupakan suatu program yang memberikan otonomi secara luas kepada sekolah serta pengambilan keputusan yang bersifat partisipatif dimana melibatkan masyarakat terutama orang tua murid secara lebih intensif dalam rangka peningkatan mutu pendidikan di sekolah. MBS bertujuan untuk memberdayakan sekolah, terutama sumber daya manusiannya (kepala sekolah, Guru, karyawan, siswa, orang tua siswa, dan masyarakat sekitarnya), melalui pemberian kewenangan, fleksibilitas, dan sumber daya lain untuk memecahkan persoalan yang dihadapi oleh sekolah yang bersangkutan. 
Ciri-ciri sekolah yang berdaya pada umumnya tingkat kemandirian tinggi/tingkat ketergantungan rendah; bersifat adaptif dan antisipatif/proaktif sekaligus; memiliki jiwa kewirausahaan tinggi (ulet, inovatitif, gigih, berani mengambil resiko, dsb); bertanggung jawab terhadap hasil sekolah; memiliki kontrol yang kuat terhadap input manajemen dan sumber dayanya; kontrol terhadap kondisi kerja; komitmen yang tinggi pada dirinya; dan dinilai oleh pencapaian prestasinya.

Wacana desentralisai pendidikan muncul sejak diberlakukan UU tentang Otonomi Daerah Pasal 11 UU Nomor 22 tahun 1999 menyebutkan bahwa pendidikan merupakan salah satu bidang pemerintahan yang wajib dilaksanakan oleh pemerintah daerah. Kebijakan ini memberikan kesempatan dan keleluasaan kepada daerah untuk memberdayakan pendidikan berdasarkan kebutuhan masyarakat setempat. Pemerintah daerah diharapkan senantiasa meningkatkan kemampuannya dalam berbagai tahap pembangunan pendidikan, sejak tahap perumusan kebijakan daerah, perencanaan, pelaksanaan, sampai pemantauan di daerah masing-masing.

Manajemen Berbasis Sekolah (MBS) merupakan satu kajian yang banyak dibahas untuk mengubah sistem pendidikan yang sentralistik ke arah Desentralistik. Densentarlisasi pendidikan memberi kewenangan kepada sekolah dan masyarakat setempat untuk mengelola pendidikan. Dengan demikian dapat diharapkan tercapai peningkatan kerjasama antara kepala sekolah, guru, pegawai lainnya, dan masyarakat, serta peningkatan kualitas dan produktivitas pendidikan. Hal tersebut juga akan membentuk kemadirian sekolah yang selama ini kurang ditekankan, sehingga fungsi-fungsi yang ada akan didesentralisasikan di sekolah.

Pelaksanaan MBS secara efektif dan efisien menuntut seorang kepala sekolah yang memiliki pandangan luas tentang sekolah dan pendidikan. Kepala sekolah dituntut untuk melakukan fungsinya sebagai manajer sekolah dalam meningkatkan pembelajaran, dengan melakukan supervisi kelas, membina dan memberikan saran positif kepada guru. Kepala sekolah juga harus melakukan tukar pikiran, sumbang saran, dan studi banding antar sekolah untuk menyerap kiatkiat kepemimpinan dari kepala sekolah lain.
SMP Negeri se Kecamatan Pahandut adalah sekolah-sekolah yang telah menerapkan program Manajemen Berbasis Sekolah di Palangka Raya. Oleh karena MBS memberi kewenangan kepada sekolah untuk menentukan kebijakan dan program sendiri yang tidak sama antara sekolah yang satu dengan sekolah yang lain. Sekolah menengah pertama yang ada di Kecamatan Pahandut terdapat 4 (empat) sekolah, dari kempat sekolah tersebut tentu ada sekolah yang kelihatannya lebih menonjol dan lebih dikenal oleh masyarakat, hal ini dikarenakan beberapa faktor salah satunya adalah kepemimpinan seorang kepala sekolah. Tentu saja setiap pemimpin memiliki kebijakan yang berbeda dengan pemimpin yang lain, baik dalam penerapan kerja dan kemampuan nya dalam memimpin untuk mencapai tujuan organisasinya.

\section{KESIMPULAN DAN SARAN}

\section{Kesimpulan}

Berdasarkan hasil analisis data dapat disimpulkan sebagai berikut: (1) Deskripsi Kepemimpinan Kepala Sekolah memiliki nilai kategori rata-rata "Baik", (2) Deskripsi Manajemen Berbasis Sekolah memiliki kategori rata-rata "Baik", (3) terdapat hubungan positif yang signifikan antara Kepemimpinan Kepala Sekolah terhadap Manajemen Berbasis Sekolah di Sekolah Menengah Pertama (SMP) Negeri se Kecamatan Pahandut Kota Palangka Raya secara langsung yang sangat kuat/sangat tinggi, sehingga dengan demikian tinggi rendahnya kepemimpinan kepala sekolah sangat mempengaruhi tingkat keberhasilan manajemen berbasis sekolah di Sekolah Menengah Pertama (SMP) Negeri se Kecamatan Pahandut Kota Palangka Raya.

\section{Saran}

Berdasarkan kesimpulan, terdapat saran yang dapat digunakan, yaitu (1) bagi Kepala Sekolah diharapkan agar memberi respon atau tanggapan bagi guru-guru dalam menjalin kerjasama guna meningkatkan manajemen berbasis sekolah supaya dapat terjalin hubungan dengan baik, (2) bagi guru diharapkan hubungan Kepemimpinan Kepala sekolah terhadap manajemen berbasis sekolah di SMP Negeri se Kecamatan Pahandut 
Kota Palangka Raya yang sudah dilakukan dengan baik tersebut, hendaknya dipertahankan dan lebih ditingkatkan guna perbaikan mutu dan peningkatan kualitas pendidikan, dan (3) bagi masyarakat agar meningkatkan kepedulian dan lebih berpartisipasi dengan pihak sekolah dalam membuat berbagai keputusan agar tidak terjadi kesalah pahaman antara orang tua/wali dari siswa, misal melalui Dewan Sekolah/Komite. .

\section{DAFTAR RUJUKAN}

Moore, G. W. 1983. Develping and Evaluating Education Research. Boston: Little, Brow \& Company.
Sudijono, Anas. 2005. Pengantar Statistik Pendidikan. Jakarta: PT. Raja Grafindo Persada.

Suryabrata, Sumadi. 1993. Metode Penelitian. Jakarta: CV. Rajawali.

Undang-Undang Tahun 2003. Tentang Sistem Pendidikan Nasional. (Undang-Undang Sisdiknas).

Undang-Undang Nomor 22 Tahun 1999. Pemerintah Daerah. Jakarta: Novindo Pustaka Mandiri.

Undang-Undang Nomor 25 Tahun 1999. Perimbangan Keuangan antara Pemerintah Pusat dan Daerah. Jakarta: Biro Humas Departemen Dalam Negeri. 